\title{
Kinetic study of Mongolian coals by thermal analysis
}

\author{
S.Jargalmaa*, G.Tsatsral, M.Battsetseg, D. Batkhishig, A. Ankhtuya, \\ J.Namkhainorov, B.Bat-Ulzii, B.Purevsuren, B.Avid
}

Institute of Chemistry and Chemical Technology, Mongolian Academy of Sciences, MAS $4^{\text {th }}$ building,

Peace Avenue, Bayanzurkh district, Ulaanbaatar 13330, Mongolia

*Corresponding author: jargalmaasoninkhuu@gmail.com

Received: 24 October 2017; revised: 18 December 2017; accepted: 19 December 2017

\begin{abstract}
Thermal analysis was used for the thermal characterization of the coal samples. The experiments were performed to study the pyrolysis and gasification kinetics of typical Mongolian brown coals. Low rank coals from Shivee ovoo, Ulaan ovoo, Aduun chuluun and Baganuur deposits have been investigated. Coal samples were heated in the thermogravimetric apparatus under argon at a temperature ranges of $25-1020^{\circ} \mathrm{C}$ with heating rates of $10,20,30$ and $40^{\circ} \mathrm{C} / \mathrm{min}$. Thermogravimetry (TG) and derivative thermogravimetry (DTG) were performed to measure weight changes and rates of weight losses used for calculating the kinetic parameters. The activation energy $\left(E_{a}\right)$ was calculated from the experimental results by using an Arrhenius type kinetic model.
\end{abstract}

Keywords: Coal, activation energy, DTG, TG

\section{INTRODUCTION}

Compared to crude oil and natural gas, coal is more evenly distributed in worldwide and often readily accessible e.g. by open-pit mining. Because of instability of the world oil market, the diversification of energy carriers is practically implemented in many countries with involvement of various nontraditional types of organic raw materials, primarily coal whose reserves are much greater than oil and gas reserves [1].

Coal total resources in Mongolia currently stands at about 175.5 billion tons and a proven coal reserve is 34 billion tons including from lignite to bituminous coals [2]. In Mongolia, coal is main energy carrier for thermal power plants and local boiler houses and there is almost no other form of large scale coal use [3]. Coal reserves mostly occur in a large brown coal basin located in the central economic region of Mongolia, which contains the Baganuur, Ovdogkhudag, Aduunchuluun, Tevshiin govi, Khuut, Tsaidam nuur and Shivee ovoo deposits. Coal samples from Baganuur, Bayanteeg and Shivee ovoo deposits have been assessed for pyrolysis, hydrogenation and gasification. Samples also from Ovdogkhudag and Aduunchuluun deposits have been assessed for their liquefaction potential using facilities in Japan [4]. Thermal analysis has been widely used in the recent years for the investigation of combustion and pyrolysis behavior of fossil fuels such as coal, oil shales and tar sands. Thermal properties of coal play a significant role industry and impact on coal combustion on environmental pollution. Converting coal into oil and gas allows coal to be utilized as an alternative fuel, which will affect the national security and the economically sustainable development. Thermogravimetry is usually used as a means of determing pyrolytic characteristics and kinetic parameters. Thermogravimetry measures the weight change of a tested material as a function of temperature or time in a controlled atmosphere, such as nitrogen atmosphere or argon. Measurements are used primarily to determine the composition of materials and to predict their thermal stability at temperatures up to $1000^{\circ} \mathrm{C}$. The technique can characterize materials that exhibit weight loss or gain during the heating process due to: decomposition, oxidation or dehydration. The various weight loss processes determined during the thermogravimetry reflect the physical and chemical structural changes during the conversion. Kinetics studies have become a crucial point in thermal analysis, in which the main purpose is to determine the mechanism of decomposition and to calculate the parameters of the Arrhenius equation. The kinetic study of coal is of special importance, constituting the initial step of the combustion, liquefaction and gasification process [7]. Low rank coals, including lignite and sub-bituminous coals have low metamorphic grade and it accounts for almost half of coal reserves of the world. There is a necessity to exploit and utilize low rank coals, even they have high moisture and low calorific value. For the experiments, some low ranks coals from Mongolia were chosen.

(C) The Author(s). 2017 Open access This article is distributed under the terms of the Creative Commons Attribution 4.0 International License (http://creativecommons.org/licenses/by/4.0/), which permits unrestricted use, distribution, and reproduction in any medium, provided you give appropriate credit to the original author(s) and the source, provide a link to the Creative Commons license, and indicate if changes were made. 


\section{EXPERIMENTAL}

The analytical samples of coals from these 4 deposits were prepared according to Mongolian National Standards (MNS 2719:2001) and main technical specifications including moisture (MNS 656:79), ash (MNS 652:79), volatile matter (MNS 654:79), caloric value (MNS 669:87) and sulfhur (MNS 895:79) have been determined. The thermogravimetric experiments were conducted at the TG/DTA7300 apparatus. For these tests, a $10 \mathrm{mg}$ of coal sample was heated to $1020^{\circ} \mathrm{C}$ with heating rates of $10,20,30$ and $40^{\circ} \mathrm{C} / \mathrm{min}$ using argon as a purge gas.

\section{RESULTS AND DISCUSSION}

The proximate and ultimate analyses of the samples from Ulaan ovoo, Shivee ovoo, Baganuur and Aduun chuluun were performed and the obtained results are given in Table1.
Aduun chuluun, which is a good from the environmental point of view. The content of sulfur is $2.22 \%$ for Aduun chuluun, and it belongs to the coal with middle sulfur content. Ulaan ovoo is a sub-bituminous, while Baganuur, Shivee ovoo and Aduun chuluun coals are lignites [1].

Figure 1 shows the weight losses for Aduun chuluun, Ulaan ovoo, Shivee ovoo and Baganuur coals at different heating rates as $10,20,30,40^{\circ} \mathrm{C} / \mathrm{min}$.

The weight of the sample was continually dropped with increasing of the temperature beyond $700^{\circ} \mathrm{C}$, which could be attributed to the possibility of continued pyrolysis. The carbon dioxide, which evolved as a residual of the carbonate decomposition may react with the residual char, as described by the Boudouard reaction, forming carbon monoxide. This finding also shows that the rate of decomposition of the hydrocarbon material loss during the pyrolysis phase is almost invariant irrespective of the

Table 1. The results of ultimate and proximate analysis of coal samples

\begin{tabular}{|c|c|c|c|c|c|c|c|c|}
\hline \multirow{2}{*}{ Samples } & \multicolumn{4}{|c|}{ Proximate analysis } & \multicolumn{4}{|c|}{ Ultimate analysis } \\
\hline & $\mathbf{W}^{\mathbf{a}}$ & $A^{d}$ & $\mathbf{V}^{\text {daf }}$ & $S_{t}^{a}$ & $\begin{array}{c}\mathbf{Q}^{\text {daf }} \\
\text { (kcal/kg) }\end{array}$ & $\mathrm{C}^{\text {daf }}$ & $\mathrm{H}^{\text {daf }}$ & $\begin{array}{c}\mathrm{N}+\mathrm{O}+ \\
\text { different }\end{array}$ \\
\hline Aduun chuluun & 20.16 & 13.54 & 48.00 & 2.22 & 6362 & 66.75 & 4.93 & 27.65 \\
\hline Ulaan ovoo & 5.10 & 4.88 & 46.82 & 0.72 & 6428 & 74.60 & 4.93 & 27.40 \\
\hline Shihvee ovoo & 13.41 & 21.17 & 42.57 & 1.06 & 6501 & 71.35 & 4.99 & 23.05 \\
\hline Baganuur & 8.50 & 5.90 & 36.50 & 0.68 & 6848 & 70.53 & 5.74 & 21.48 \\
\hline
\end{tabular}
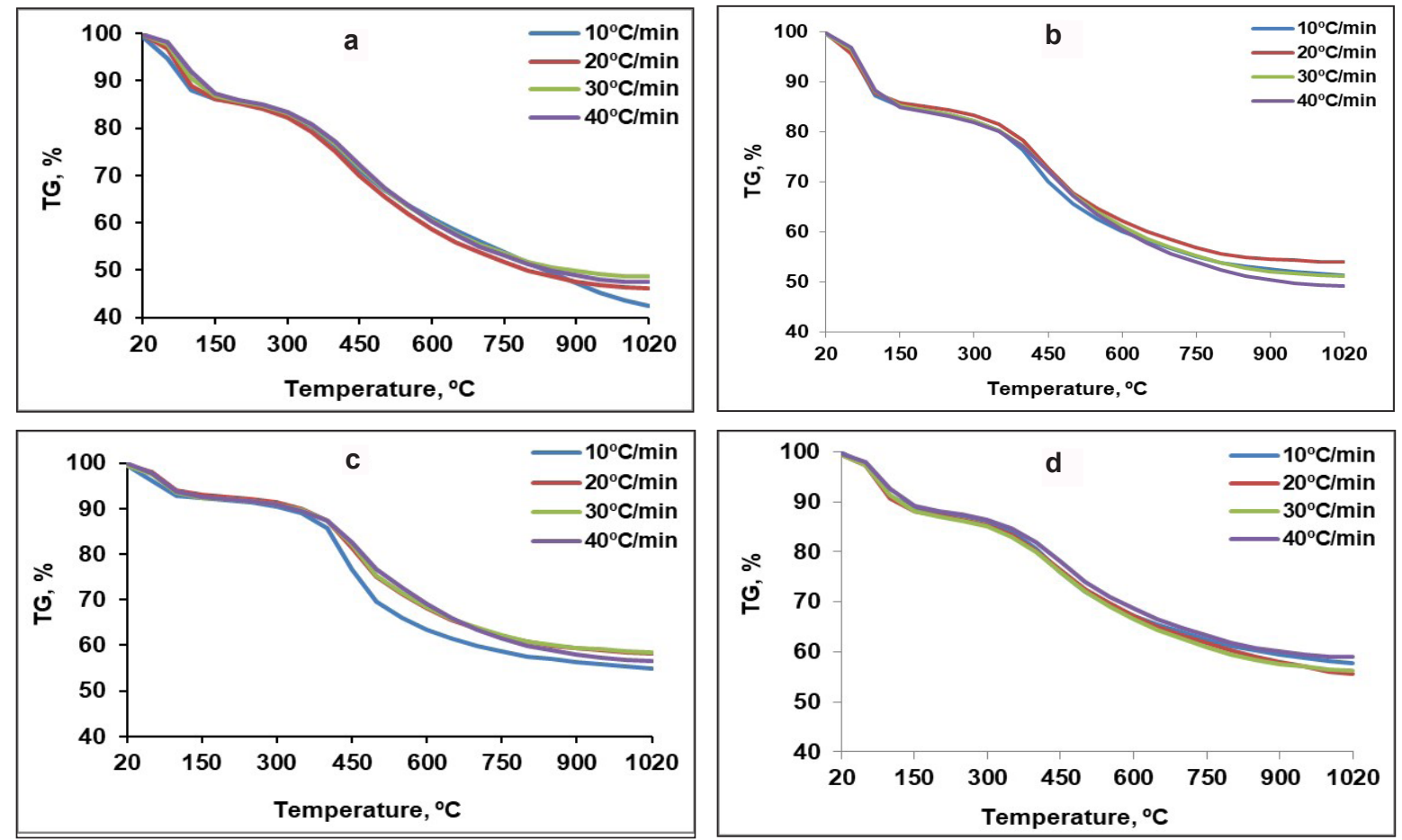

Fig. 1. Weight loss of coals a-Aduun chuluun, b-Baganuur, c-Ulaan ovoo, d-Shivee ovoo

Ulaan ovoo has the lowest ash and moisture and the highest carbon content within the investigated four coals. Aduun chuluun was a coal with the highest content of moisture among the coals. Baganuur coal has low ash content and low volatile matter.

The content of sulfur is less than $1.5 \%$ in all coals except heating rate applied. As the heating rates increased, the maximum rate of decomposition was also increased. Similar behavior of the weight loss of coal at different heating rates was reported [6].

Figure 2 shows the DTG curves of the Aduun chuluun, Shivee ovoo, Ulaan ovoo and Baganuur coals. 
From the Figure 2 it is seen that the DTG curves can be divided into three zones. Zone I represents the evolution of the water and it occurs below $200^{\circ} \mathrm{C}$. It was observed
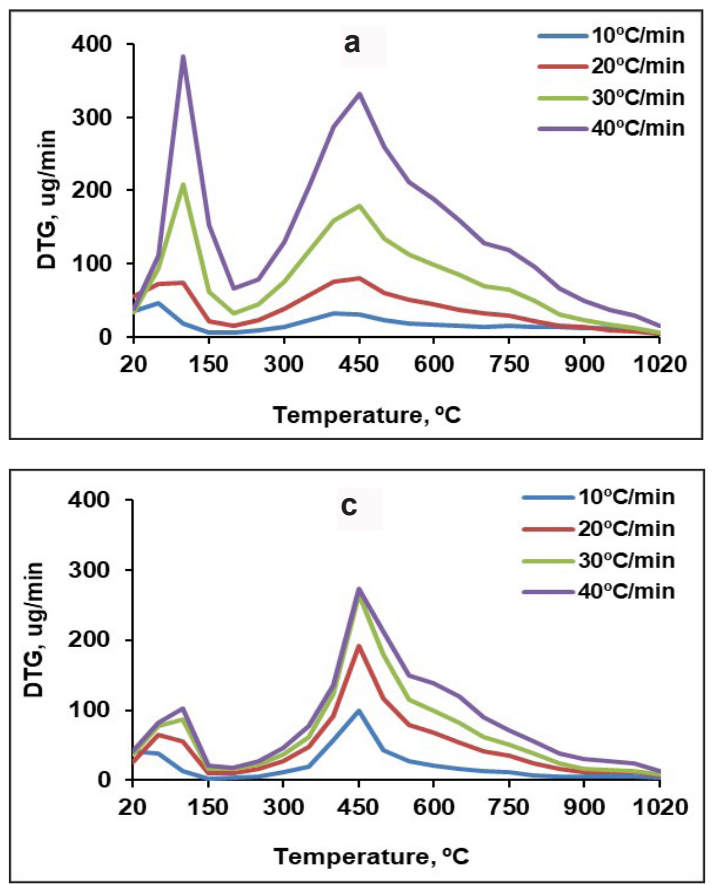

$500^{\circ} \mathrm{C}$, different processes take place prior to primary pyrolysis, disruption of the hydrogen bonds, vaporization and transport of the non covalent bonded molecular
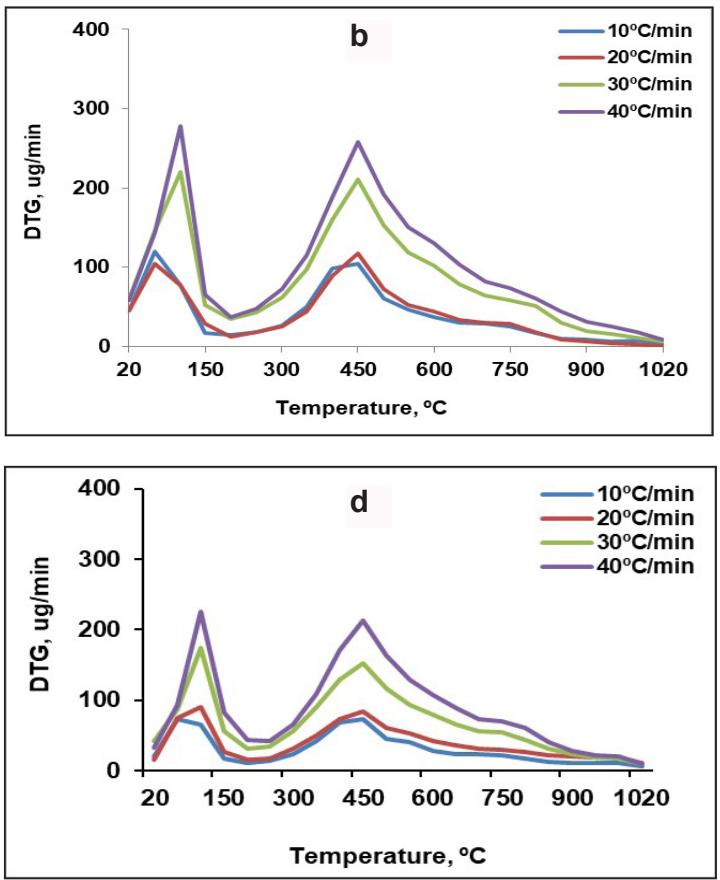

Fig. 2. DTG curves of coals

a-Aduun chuluun, b-Baganuur, c-Ulaan ovoo, d-Shivee ovoo

Table 2. Maximum rate of decomposition (\%/min) for the coals at the different rates (Zone II)

\begin{tabular}{ccccc}
\hline Heating rate, ${ }^{\circ} \mathbf{C} /$ min & Aduun chuluun & Ulaan ovoo & Shivee ovoo & Baganuur \\
\hline 10 & 1.114 & 2.214 & 1.009 & 1.307 \\
20 & 2.219 & 3.206 & 1.785 & 2.524 \\
30 & 3.278 & 4.787 & 2.741 & 3.397 \\
40 & 4.537 & 5.707 & 3.732 & 4.750 \\
\hline
\end{tabular}

in the thermogravimetric study at the low temperature region from $80^{\circ} \mathrm{C}$ to $110^{\circ} \mathrm{C}$ and the main decomposition appears in the $300^{\circ} \mathrm{C}$ to $500^{\circ} \mathrm{C}$ region, where maximum loss of volatile materials occurs due to secondary volatilization. Zone II covers also the temperature about $700^{\circ} \mathrm{C}$ and zone III exhibits the second decomposition range of $700-1020^{\circ} \mathrm{C}$. The occurrence of this pattern is probably due to the stronger chemical bonding of $\mathrm{C}-\mathrm{C}$ in higher rank coals which is difficult to break. They have been used in a wide variety of areas related to proximate analysis, coal reactivity and heat effects associated with coal pyrolysis, combustion and heat of hydrogenation. Table 2 shows that the maximum rate of decomposition was increased with the heating rate increase from $10^{\circ} \mathrm{C} /$ min to $40^{\circ} \mathrm{C} / \mathrm{min}$. DTG curves in zone I have a good correlation with moisture contents of coals determined by proximate analysis. The maximum rate of decomposition in zone II increases with increasing degree of coalification such as Ulaan ovoo> Baganuur>Aduun chuluun>Shivee ovoo. DTG curves of all samples, show the same trend in thermal behavior I having 2 or 3 peaks.

The Zone I which occur between $30^{\circ} \mathrm{C}$ to $200^{\circ} \mathrm{C}$ is due to the elimination of moisture. At temperatures below 300- phase. The two peak, where essential weight loss occurs in related to primary devolatilization, during which carbon, hydrogen and oxygen compounds are released [5]. Thermogravimetry and derivative thermogravimetry (DTG) were performed to measure weight changes and rates of weight loss used for calculating the kinetic parameters. The activation energy was calculated from the experimental results by using an Arrhenius type kinetic model. Reaction intervals, peak and maximum rate of decomposition of the coal samples were determined. It was observed that the reaction intervals of higher of decomposition of the coal samples studies varied between $200^{\circ} \mathrm{C}$ to $700^{\circ} \mathrm{C}$ depending on the properties. Kinetic energy results contribute to enhancing the knowledge on low rank coal thermal characterization, gasification and pyrolysis. The shift in the DTG main peak in the Figure 2 measures activation energy $E_{a}$. The activation energies $\mathrm{E}_{\mathrm{a}}$ were obtained using the Arrhenius relation given by equation 1 .

$$
\ln \left[\left(\frac{d W}{d t}\right) \cdot\left(\frac{1}{W}\right)\right]=\ln A_{r}-\frac{E}{R T}
$$


where:

$$
\begin{aligned}
& d W / d t \text { - rate of mass change } \\
& E \text { - activation energy } \\
& T \text { - temperature } \\
& A_{r} \text { is the Arrhenius constant }
\end{aligned}
$$

When $\ln [(\mathrm{dW} / \mathrm{dt}) \cdot 1 / \mathrm{W}]$ is plotted vs. $1 / \mathrm{T}$, a straight line is obtained which will have a slope equal to $E / R$ and from the intercept the Arrhenius constant can be estimated. The assumption of a first order reaction appears reasonable as shown in Fig. 3.
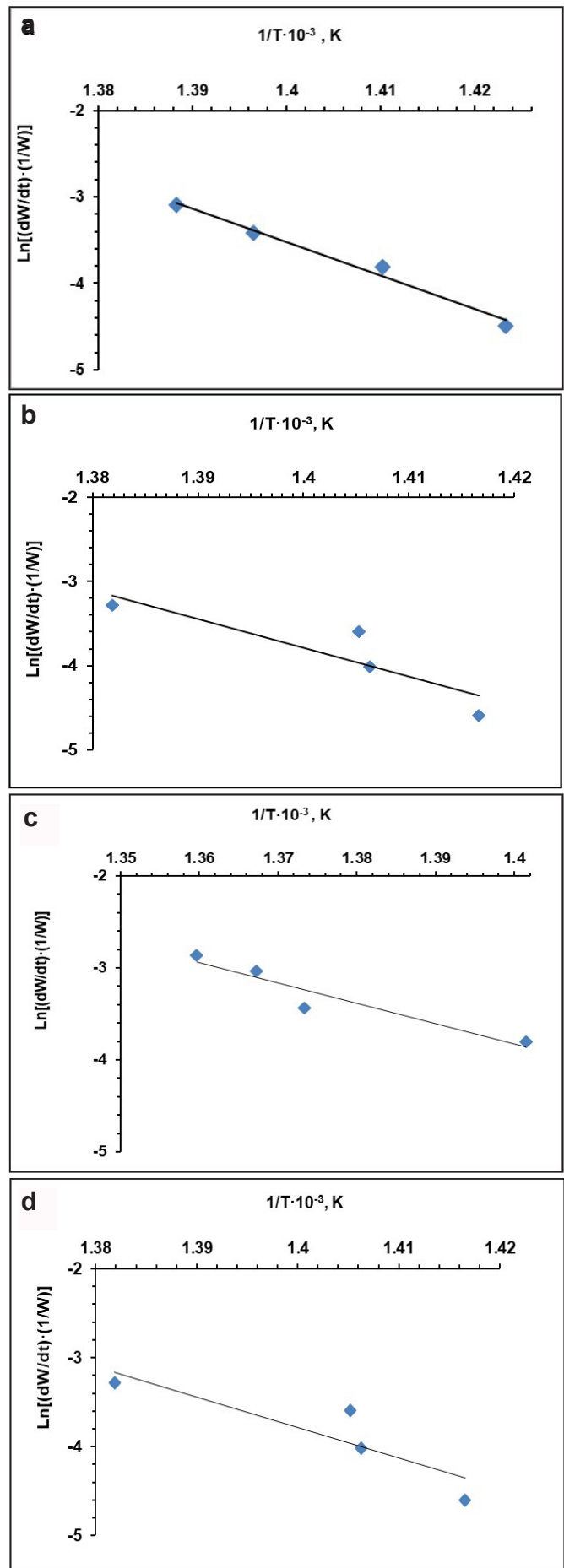

Fig. 3. Plot of first order equation for TG curves of coals a-Aduun chuluun, b-Baganuur, c-Ulaan ovoo, d-Shivee ovoo.
Table 3. Activation energies of Aduun chuluun, Shivee ovoo, Ulaan ovoo and Baganuur coals

\begin{tabular}{lcc}
\hline Coal types & $\begin{array}{l}\text { Zone I } \\
\left(\mathbf{E}_{\mathrm{a},} \mathbf{k J / m o l}\right)\end{array}$ & $\begin{array}{l}\text { Zone II } \\
\left(\mathbf{E}_{\mathrm{a},} \mathbf{k J / m o l}\right)\end{array}$ \\
\hline Aduun chuluun & 31.84 & 321.91 \\
Shivee ovoo & 50.60 & 284.32 \\
Ulaan ovoo & 53.21 & 182.15 \\
Baganuur & 50.60 & 284.49 \\
\hline
\end{tabular}

Kinetic studies of coal gasification and pyrolysis are important in the design and operation of gasification power plants. Data of activation energy have been determined for the coal pyrolysis process. These results can provide useful information to predict a kinetic model of coal pyrolysis and optimization of the process conditions.

\section{CONCLUSION}

Dewatering degrees of coals shown in zone I have a good correlation with the moisture contents of coals determined by proximate analysis. Maximum rates of decomposition in zone II increases with increasing degree of coalification such as Ulaan ovoo $>$ Baganuur $>$ Aduun chuluun $>$ Shivee ovoo. The maximum rate of decomposition for the coals were increased as the heating rates increased. For all brown coals, activation energies are $30-54 \mathrm{~kJ} / \mathrm{mol}$ in the zone I, $180-320 \mathrm{~kJ} / \mathrm{mol}$ in the zone II.

\section{REFERENCES}

1. Purevsuren B., Davaajav Ya., Erdenechimeg R. (2010) Investigation on largest coal deposits in Mongolia. Toonotprint publisher, Ulaanbaatar, 25-33 (in Mongolian).

2. Jargalmaa S., Purevsuren B., Davaajav Ya., Avid B., Bat-Ulzii B., et al. (2015) Investigation on characterization of Ereen coal deposit. Mong. J. Chem., 16(42), 18-21

3. Ariunaa A., Bernhardt D., Backmann M., Gebauer K., Hack N., et al. (2015) Research on the thermal decomposition of Mongolian Baganuur lingnite and Naryn sukhait bituminous coal. Mong. J. Chem., 16(42), 22-29

4. Batbileg S., Purevsuren B., Davaajav Ya., Namkhaivorov J., Krooss M., et al. (2015) Characterization of solid and liquid products obtained from thermal processing of Khoot coal and evaluation of char-made activated carbon adsorption. Sustain. Environ. Res., 25(3), 159-165

5. Iffet Yakat Elbeyli., Sabriye piskin., Hale Sutsu. (2004) Pyrolysis kinetics Of Turkish bituminous coals by thermal analysis. J. Env. Sci., 28, 233-239

6. Nor Fadzilah Othman., Mohd Hariffin Boosroh. (2009) Pyrolysis study of Sarawak coal using thermogravimetric analysis. International energy journal, 10, 195-200

7. Jayarman K., Bonifaci E., Merlo N., Gokalp. (2013) High ash Indian and Turkish coal pyrolysis and gasification studies in various ambiences. Cesme, Izmir, Turkey., 8, 8-13 